\title{
Investigations of the effectiveness of lead disposal from hard coal through the cleaning process
}

\author{
Dorota Makowska1,a, Andrzej Strugała1 ${ }^{1}$ Faustyna Wierońska ${ }^{1}$ and Adam Włodek ${ }^{2}$ \\ ${ }^{1}$ AGH University of Science and Technology, Faculty of Energy and Fuels, Al. A. Mickiewicza 30, 30-059 Krakow, Poland \\ ${ }^{2}$ A GH University of Science and Technology, Faculty of Geology, Geophysics and Environmental Protection, Al. A. Mickiewicza 30, 30-059 \\ Krakow, Poland
}

\begin{abstract}
Lead, belonging to the category of toxic heavy metals, poses a major threat to the environment and the health and life of living organisms. Anthropogenic sources of lead emissions to the atmosphere include coal combustion, pyrolysis and gasification processes. This metal enters the atmosphere through the fly ashes and gases, causing chemical imbalance in the ecosystem. One way of reducing the emissions of heavy metals into the atmosphere due to the thermochemical processing of coal involves removing impurities from the fuel prior to its use, e.g. through the coal cleaning processes. The removal of heavy metals from coal through these processes is possible due to the fact that these elements are mostly related to the mineral matter, which is separated from the organic matter. This paper presents the results of investigations of the removal efficiency of lead from coals through the coal cleaning processes in industrial plants. Additionally, the distribution of lead among individual products of these processes was identified. Raw coals, coal concentrates, intermediate products and waste from five plants of mechanical processing of coking coal were analyzed. The determination of the lead content was performed with the use of Flame Atomic Absorption Spectrometry (FAAS). Moreover, for all the samples, a proximate analysis and ultimate analysis as well as the determination of the content of main elements of mineral matter were conducted. In order to confirm the mode of occurrence of lead in coal mineral matter, an elemental analysis was conducted with the use of an electron microprobe. The results of the investigations showed that with a significant reduction of mineral matter in the coal cleaning processes, the lead content is decreased, as a result of both, the application of the gravity and flotation methods. The analyzed metal accumulates primarily in the waste and/or intermediate products of coal cleaning. The lead content in the obtained coal concentrates does not exceed $25 \mathrm{mg} / \mathrm{kg}$. The microprobe examinations confirmed the presence of lead in sulphides, mainly in the form of galena.
\end{abstract}

\section{Introduction}

Lead belongs to the group of heavy metals (metals with density greater than $4.5 \mathrm{~g} / \mathrm{cm}^{3}$ ) with an extremely harmful effect. It can enter the body through inhalation, ingestion (water, food), and through the skin, and cause immune function disorders, renal disfunctions, or neurotoxic and reproductive disorders [1]. This metal exhibits a toxic effect and is unnecessary for the proper functioning of living organisms. Therefore, $\mathrm{Pb}$ poses a major threat to the natural environment as well as health and life [2-3].

One of the major anthropogenic sources of lead emission to the environment is constituted by the thermochemical coal processes (mostly combustion). In Poland, nearly the entire amount of electricity and heat is obtained from hard and brown coal combustion [4]. Therefore, the industrial and nonindustrial combustion processes cause the release of 466 tons of lead to the atmosphere per year, representing $83 \%$ of total lead emission resulting from human activities [5].

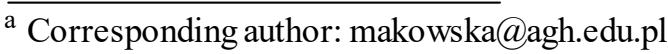

The large share of the combustion processes in lead emission can be attributed to the fact that coal is usually enriched with heavy metals, including lead [6]. A number of geochemical research works have shown that Polish coals, i.e. not only those from the Upper Silesian Coal Basin (USCB) and of the Lublin Coal Basin (LCB) but also those from the Lower Silesian Coal Basin LSCB (no longer exploited) contain a higher amount of lead compared to the world average content of this element in hard coal. The average content of $\mathrm{Pb}$ in the coals of the USCB was $19 \div 28 \mathrm{mg} / \mathrm{kg}$ (ppm) [7-12]. Differentiation of the lead distribution in each layer of this basin and the impact of coal organic and inorganic matter on the $\mathrm{Pb}$ content indicates the great dynamic processes of accumulation and dispersion of this element [13]. Solutions rich in lead, flowing through the bed at every stage of its creation, were the main factor affecting the lead content in organic and inorganic coal matter. Lead is generally associated with coal mineral matter. It occurs mainly in sulphides ( $\mathrm{PbS}$ - galena, $\mathrm{PbSe}$ - clausthalite) [14] and can be associated with pyrite $\left(\mathrm{FeS}_{2}\right)$ [15]. It may also be present in alumino-silicates 
and carbonates [16-18]. Studies [19-20] on the coals from the USCB have linked lead mainly with the mineral matter. Coals from the Chełm deposits of the LCB are characterized by a similar lead content $(27 \mathrm{mg} / \mathrm{kg})$ to coals from the USCB [21]. These coals also have shown a higher affinity of lead to the mineral matter than to the organic matter of coal. The coking coals from the LSCB contain a higher amount of $\mathrm{Pb}$ with the average value of $32.7 \mathrm{mg} / \mathrm{kg}$ [22].

The coal combustion processes result in the enrichment of solid by-products with heavy metals. Lead passes primarily to fly ash and flue dust [23]. The enrichment factor for these products, i.e. the ratio of the $\mathrm{Pb}$ content in the product to its contents in the combusted coal, is 3.78 and 21.11 , respectively. The fly ash from the combustion of the coals from the USCB accumulates lead mainly in particles with a grain size of less than $100 \mu \mathrm{m}$ [24]. For the ash grains $<10 \mu \mathrm{m}$, the lead content was $265 \mathrm{ppm}(\mathrm{mg} / \mathrm{kg})$. These results are confirmed by other researchers [25], and support the view [26] about an increase in the content of elements in the series of As-Se-Sb-Zn-Pb-Cd-Hg with a decrease in the particle diameter of the solid by-products of coal combustion. The enrichment of these products depends on the ionization potential and the vaporization temperature of the elements [27-29]. The highest content of $\mathrm{Pb}$ was found in a group of fly ash particles with a size less than $20 \mu \mathrm{m}$ comprising mainly magnetite. The lead content in the solid by-products of combustion depends primarily on its mode of occurrence in coal (connection with mineral or organic matter) [30-31]. Combustion conditions are of secondary importance.

The smallest particles of fly ash $(<10 \mu \mathrm{m})$ are not fully captured from the flue gas and get into the atmosphere in the form of suspended particles (TSP). The study [32] demonstrated the effect of combustion on the emission of lead into the atmosphere through dust. The concentration of $\mathrm{Pb}$ in the TSP increased 1.5 times during the heating season.

In the pyrolysis processes, lead also has a tendency to pass to the gas phase at temperatures above $700{ }^{\circ} \mathrm{C}$ [33]. However, about $50 \%$ of lead remains in the solid phase (char or coke) up to $1000{ }^{\circ} \mathrm{C}$. In addition, pyrolysis changes the mode of lead occurrence in solid residues. This was confirmed by other studies [34]. It has been shown that the lead sulphides, which were considerably quantitatively higher than other forms of lead bonding, were reduced in char relative to the raw coal, contrary to the other forms of $\mathrm{Pb}$ (carbonate, organic, aluminosilicate and pyrite).

Currently Poland's policy is to reduce the emissions of heavy metals, i.e. $\mathrm{Hg}, \mathrm{Pb}$ and $\mathrm{Cd}$ into the atmosphere [35]. Reducing the emission of these metals from coal combustion, pyrolysis and gasification is possible to achieve in two ways: (1) by removing pollutants from fossil fuels before they are used in industrial processes, or (2) by the purification of exhaust and flue gases [3638]. The first group of methods includes the coal cleaning processes. Among them gravity methods (enrichment in the heavy media and jigs) and flotation methods can be distinguished [39]. These processes involve the removal of mineral matter from raw coal (feed), resulting in a high- quality coal concentrate. Therefore, the removal of lead from coal by its cleaning is possible due to lead association with coal mineral matter, mainly in sulphide form.

Studies [40-41] on the removal of heavy metals, (including lead) from coal by the coal cleaning process in a dense medium on a laboratory scale were carried out. These studies confirmed lead affinity to coal mineral matter and the possibility of its removal from the raw coal through this process. The preliminary study [42] on the possibility of reducing the content of selected heavy metals (lead, zinc, copper, chromium, manganese, and nickel) from hard coals by their enrichment was also conducted by the authors of this paper. Tests of samples from two coking coal preparation plants have shown that the content of these metals can be effectively reduced by up to about $80 \%$. In the case of lead, the coal cleaning in dense media resulted in a reduction of its content up to $56 \%$; enrichment in jigs removed $44 \%$ of $\mathrm{Pb}$, and in the case of flotation - $30 \%$. The lead content in the coal concentrates did not exceed $16 \mathrm{mg} / \mathrm{kg}$.

The research carried out within the framework of this study was conducted to determine the mode of lead occurrence and to confirm the results obtained in earlier studies on the possibility of lead removal from coal by its enrichment in industrial coal preparation plants. It was possible by way of expanding the scope of research.

\section{Experimental}

\subsection{Examined material}

The examined material consisted of samples from the coal preparation plants of five Polish coking coal mines. The study focused on both, samples of raw coal (coal output) as well as on individual products of the coal cleaning processes. Each of the processing plants conducts the enrichment of coal in a different way. In view of the above, a summary of the examined mines and a description of the coal cleaning processes are shown in Table 1.

Table 1. Description of examined coal cleaning processes.

\begin{tabular}{|c|c|c|c|}
\hline \multirow{2}{*}{$\stackrel{.}{\Sigma}$} & \multicolumn{3}{|c|}{ Sections of coal cle aning process } \\
\hline & $\begin{array}{l}\text { Dense medium } \\
\text { washer (grain } \\
\text { class) }\end{array}$ & $\begin{array}{l}\text { Jig washery } \\
\text { (grain class) }\end{array}$ & $\begin{array}{l}\text { Flotation } \\
\text { (grain } \\
\text { class) }\end{array}$ \\
\hline A & $\begin{array}{c}\text { Yes }(20 \div 150 \mathrm{~mm}) \\
\text { two-product dense } \\
\text { media bath DISA }\end{array}$ & $\begin{array}{c}\text { Yes }(0 \div 20 \mathrm{~mm}) \\
\text { two-product water } \\
\text { pulsation jigs }\end{array}$ & \multirow{5}{*}{$\begin{array}{c}\text { Yes } \\
(<0.5 \mathrm{~mm} \\
\text { from } \\
\text { dewatering of } \\
\text { jig wash } \\
\text { product }) \\
\text { Flotation } \\
\text { machines IZ }\end{array}$} \\
\hline $\mathrm{B}$ & No & $\begin{array}{c}\text { Yes }(0 \div 80 \mathrm{~mm}) \\
\text { three-product water } \\
\text { pulsation jigs }\end{array}$ & \\
\hline $\mathrm{C}$ & $\begin{array}{l}\text { Yes }(20 \div 150 \mathrm{~mm}) \\
\text { three-product dense } \\
\text { media bath DISA }\end{array}$ & $\begin{array}{c}\text { Yes }(0 \div 20 \mathrm{~mm}) \\
\text { three-product water } \\
\text { pulsation jigs }\end{array}$ & \\
\hline $\mathrm{D}$ & $\begin{array}{c}\text { Yes }(20 \div 200 \mathrm{~mm}) \\
\text { three-product dense } \\
\text { media bath DISA }\end{array}$ & $\begin{array}{c}\text { Yes }(0 \div 20 \mathrm{~mm}) \\
\text { three-product water } \\
\text { pulsation jigs }\end{array}$ & \\
\hline $\mathrm{E}$ & $\begin{array}{c}\text { Yes }(20 \div 120 \mathrm{~mm}) \\
\text { two-product dense } \\
\text { media bath DISA }\end{array}$ & $\begin{array}{c}\text { Yes }(0 \div 20 \mathrm{~mm}) \\
\text { three-product water } \\
\text { pulsation jigs }\end{array}$ & \\
\hline
\end{tabular}


A total of 56 samples were analysed, including: raw coals, coal concentrates, intermediate products, waste and a dehydrated sediment from flotation. For the purposes of the electron microprobe analysis, samples of waste and intermediate products, which were characterized by a higher content of lead, were selected.

\subsection{Analytical methods}

For all samples, the determinations of the content of ash, total sulphur and pyritic sulphur in accordance with ISO standards were performed. For raw coals and coal concentrates, the calorific value was determined. The analysis of the lead content was performed using Atomic Absorption Spectrometry with flame atomization. The Hitachi Z-2000 spectrometer with the Zeeman background correction effect was applied. To determine the lead content all the samples were incinerated at 600 ${ }^{\circ} \mathrm{C}$ and subjected to microwave digestion in a Berghoff SpeedWave4 microwave system using concentrated nitric acid (V). The quantification limit of lead determination is equal to $0.055 \mathrm{mg} / \mathrm{dm}^{3}$ (for prepared solutions) and the relative standard deviation is equal to $10 \%$.

The microscope analysis and the phase chemical composition analysis of selected waste and intermediate products were conducted with the use of the Electron Probe Microanalyzer (EPMA) Jeol JXA-8230, located at the Laboratory of Critical Elements KGHM - AGH. The analysis of the chemical composition enabled identification of mineral phase and determination of accompanying trace elements. The polymorphic type of pyrite was determined based on visual assessment of grain shape. The detection limit of lead determination by this method equals $195 \mathrm{mg} / \mathrm{kg}$ (ppm). Samples for the microprobe analysis were taken in the form of sample cut.

\section{Results and discussion}

\subsection{Mode of lead occurrence in examined coals}

Based on the performed analyses, the correlations between the lead content and the ash, total sulphur and pyritic sulphur content in the examined samples were examined (Fig. 1-3). The aim of this analysis was to determine the association of lead with coal mineral matter and sulphides.

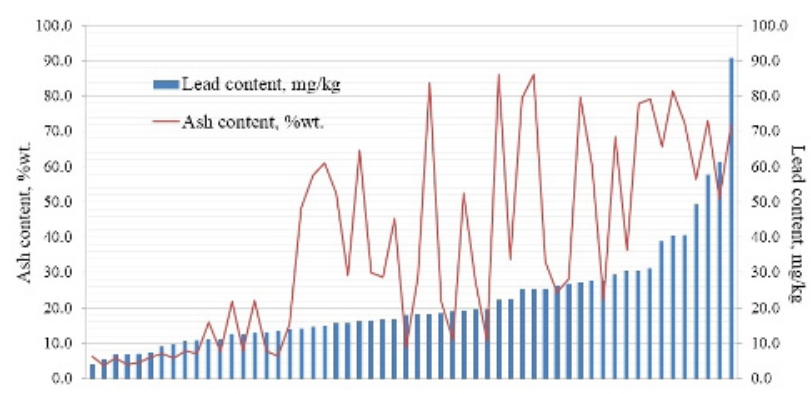

Figure 1. Correlation between lead and ash content in examined samples.

The results indicate a weak correlation between the lead content and the ash content for the examined samples (Fig. 1). However, a general increase in the content of lead can be observed along with an increase in the ash content. There is no visible relationship between the lead content and the total sulphur content for the analysed samples (Fig. 2). Nevertheless, a correlation between the lead and pyritic sulphur content (Fig. 3) is evident, which indicates the probably connection of lead with the sulphide form.

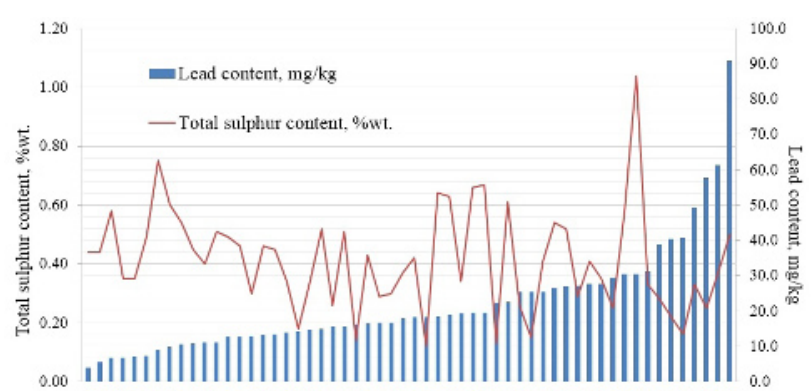

Figure 2. Correlation between lead and total sulphur content in examined samples.

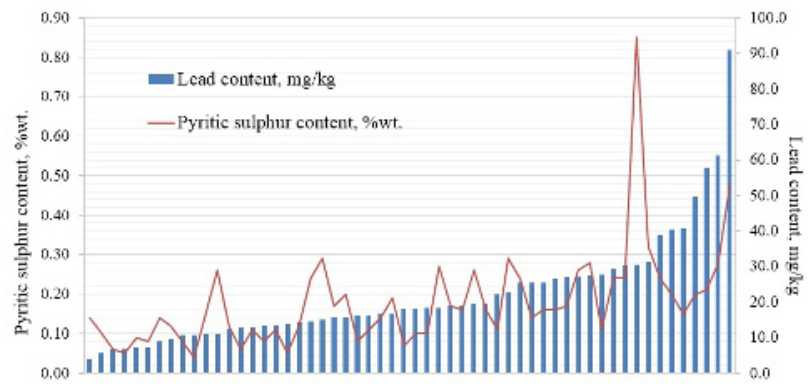

Figure 3. Correlation between lead and pyritic sulphur content in examined samples.

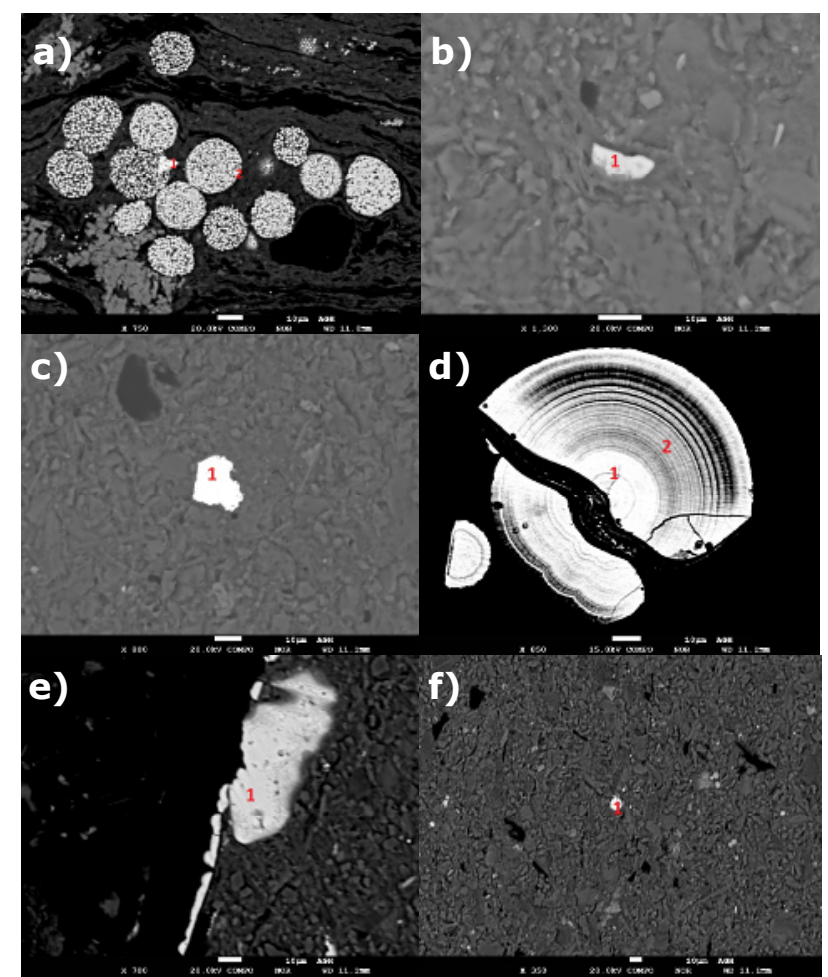

Figure 4. Results of lead content determination in sulphides: a) framboidal pyrite with chalcopyrite inclusion, b) chalcopyrite, c) galena, d) marcasite, e) pyrite, f) pyrite.

The relation between the analysed metal and the sulphide form is confirmed by the analysis of the chemical composition using a microprobe. Fig. 4 shows microscopic pictures with marked measuring points. Table 2 summarizes the results of the analysis 
of the chemical composition. The results show that, apart from lead sulphide (galena), lead can be found in relatively large amounts in other sulphides. Inclusions or individual grains of regular pyrites and concentrations of framboidal pyrite contain from 0.116 to $0.227 \%$ wt. of $\mathrm{Pb}$. Also chalcopyrite contains about $0.1 \%$ wt of lead. A high content of this metal $(0.2 \div 0.5$ wt.\%) was determined in marcasite. Additionally, carbonates, iron oxides, and alumino-silicates were analysed in respect of the lead content, but the results did not exceed the detection limit.

The results confirm the presence of lead in sulphuric form in the analysed coal and thus, the coal cleaning process aiming at removing this toxic metal becomes justified. Sulphides are characterised by a high density (chalcopyrite $3.2 \mathrm{~g} / \mathrm{cm}^{3}$; pyrite $4.95 \div 5.10 \mathrm{~g} / \mathrm{cm}^{3}$; galena $7.2 \div 7.6 \mathrm{~g} / \mathrm{cm}^{3}$ ) and they are usually located in the exterior mineral matter of coal, which may be removed through the coal cleaning processes.

Table 2. Results of analysis of sulphides.

\begin{tabular}{|c|c|c|c|c|c|}
\hline \multirow{2}{*}{ No. } & \multicolumn{4}{|c|}{ Content, \% wt. } & \multirow{2}{*}{ Mineral } \\
\cline { 2 - 5 } & $\mathbf{S}$ & $\mathbf{C u}$ & $\mathbf{F e}$ & $\mathbf{P b}$ & \\
\hline Fig. 4a -1 & 32.313 & 30.060 & 27.840 & 0.110 & chalcopyrite \\
\hline Fig. 4a - 2 & 52.752 & 0.010 & 44.934 & 0.116 & $\begin{array}{c}\text { framboidal } \\
\text { pyrite }\end{array}$ \\
\hline Fig. 4b - 1 & 30.150 & 29.186 & 24.341 & 0.098 & chalcopyrite \\
\hline Fig. 4c - 1 & 11.514 & 0.043 & 0.069 & 81.224 & galene \\
\hline Fig. 4d - 1 & 51.056 & 0.062 & 42.620 & 0.248 & marcasite \\
\hline Fig. 4d - 2 & 50.763 & 0.110 & 41.212 & 0.537 & marcasite \\
\hline Fig. 4e - 1 & 40.747 & 0.038 & 37.938 & 0.122 & pyrite \\
\hline Fig. 4f - 1 & 51.438 & 0.019 & 43.938 & 0.227 & pyrite \\
\hline
\end{tabular}

\subsection{Lead distribution in products of coal cleaning processes}

The results of the lead content determination in the analysed samples of coal and enrichment products are summarized in Table 3 . The average lead content in the tested raw coals is $22.9 \mathrm{mg} / \mathrm{kg}$, which is close to the average value of the $\mathrm{Pb}$ content in coals from USCB and more than twice the value of the world average $\mathrm{Pb}$ content in hard coal, which is $9.0 \pm 0.7$ [6]. The clark value (global average value) of lead for sedimentary rock is $12 \mathrm{mg} / \mathrm{kg}$; thus the enrichment factor EF [43] for the analyzed raw coals is 1.9. The ashes from these coals are characterized by the enrichment factor of 3.3, which constitutes a little lower value than the CAI (Coal Affinity Index), which in the case of lead is 3.9 [6] and represents the ratio of the global average lead content in the coals to the clark value of lead in sedimentary rocks.

Coal concentrates from dense medium washery contain the lowest amount of the analysed metal $(7 \mathrm{mg} / \mathrm{kg})$, while the highest concentration was determined for coal concentrates from flotation (14.3 mg/kg).

In order to better illustrate the distribution of lead among the different coal cleaning products, results are shown in the graphs (Fig. 5-7). The lead content in the feed for the enrichment in the dense media washers is at the same level for all the mines $(14.3 \div 16.2 \mathrm{mg} / \mathrm{kg})$. Coal concentrates contain a significantly lower amount of this element, i.e. from 4.0 to $11.1 \mathrm{mg} / \mathrm{kg}$. Lead accumulates mainly in waste $(28.8 \mathrm{mg} / \mathrm{kg})$ and, to a smaller extent, in intermediate products (17.6 $\mathrm{mg} / \mathrm{kg}$ ).

Table 3. Concentration of lead in individual products of coal cleaning processes.

\begin{tabular}{|c|c|c|c|c|c|c|c|}
\hline \multirow{2}{*}{$\begin{array}{c}\text { Type of } \\
\text { coal } \\
\text { cleaning }\end{array}$} & \multirow[b]{2}{*}{ Material } & \multicolumn{6}{|c|}{ Lead content, mg/kg } \\
\hline & & $\begin{array}{c}\text { Mine } \\
\text { A }\end{array}$ & $\begin{array}{c}\text { Mine } \\
\text { B }\end{array}$ & $\begin{array}{c}\text { Mine } \\
\text { C }\end{array}$ & $\begin{array}{c}\text { Mine } \\
\text { D }\end{array}$ & $\begin{array}{c}\text { Mine } \\
\text { E }\end{array}$ & Average \\
\hline \multicolumn{2}{|c|}{$\begin{array}{l}\text { Raw coals before } \\
\text { clas sification* }\end{array}$} & 13.0 & 16.9 & 19.2 & 15.7 & 49.5 & $22.9 \pm 15.1$ \\
\hline \multirow{4}{*}{$\begin{array}{c}\text { Dense } \\
\text { medium } \\
\text { washery }\end{array}$} & Raw coals & 14.3 & - & 15.0 & 16.2 & 14.6 & $15.0 \pm 0.8$ \\
\hline & $\begin{array}{l}\text { Coal } \\
\text { concentrates }\end{array}$ & 7.1 & - & 4.0 & 5.6 & 11.1 & $7.0 \pm 3.0$ \\
\hline & $\begin{array}{l}\text { Intermediate } \\
\text { products }\end{array}$ & - & - & 22.6 & 12.6 & - & $17.6 \pm 7.1$ \\
\hline & Waste & 18.4 & - & 30.6 & 40.6 & 25.4 & $28.8 \pm 9.3$ \\
\hline \multirow{4}{*}{$\begin{array}{c}\text { Jig } \\
\text { washer }\end{array}$} & Raw coals & 16.7 & 16.9 & 15.8 & 16.4 & 25.4 & $18.2 \pm 4.0$ \\
\hline & $\begin{array}{l}\text { Coal } \\
\text { concentrates }\end{array}$ & 6.8 & 9.0 & 6.7 & 7.2 & 12.8 & $8.5 \pm 2.6$ \\
\hline & $\begin{array}{l}\text { Intermediate } \\
\text { products }\end{array}$ & - & 18.5 & 19.5 & 27.6 & 27.0 & $23.2 \pm 4.8$ \\
\hline & Waste & 22.2 & 25.4 & 31.3 & 27.3 & 40.4 & $29.3 \pm 7.0$ \\
\hline \multirow{4}{*}{ Flotation } & Raw coals & 27.7 & 30.4 & 26.4 & 18.2 & 11.0 & $22.7 \pm 8.0$ \\
\hline & $\begin{array}{l}\text { Coal } \\
\text { concentrates }\end{array}$ & 18.0 & 19.5 & 9.7 & 10.6 & 13.5 & $14.3 \pm 4.4$ \\
\hline & Waste & 61.2 & 29.4 & 57.7 & 38.8 & 91.0 & $55.6 \pm 23.8$ \\
\hline & $\begin{array}{l}\text { Dehydrated } \\
\text { sediments }\end{array}$ & 13.8 & - & - & 10.8 & 13.3 & $12.6 \pm 1.6$ \\
\hline
\end{tabular}

*) raw coal before grain segregation into two sorts processed in dense media bath or in jig washers.

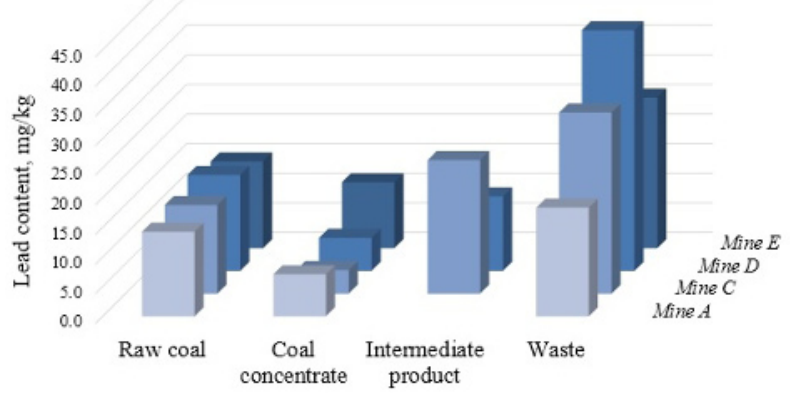

Figure 5. Lead distribution in products of dense media washers.

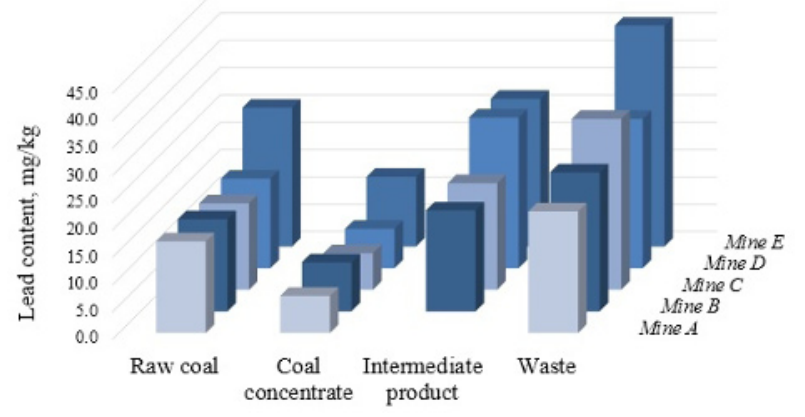

Figure 6. Lead distribution in jig washers.

The coal intended for cleaning in the jigs has an average of $18.2 \mathrm{mg} \mathrm{Pb}$ per $\mathrm{kg}$ of the tested material; 
in the case of coal concentrates the $\mathrm{Pb}$ content do not exceed $12.8 \mathrm{mg} / \mathrm{kg}$. The $\mathrm{Pb}$ contents in waste and intermediate products are similar to each other and are equal to $29.3 \mathrm{mg} / \mathrm{kg}$ and $23.2 \mathrm{mg} / \mathrm{kg}$, respectively.

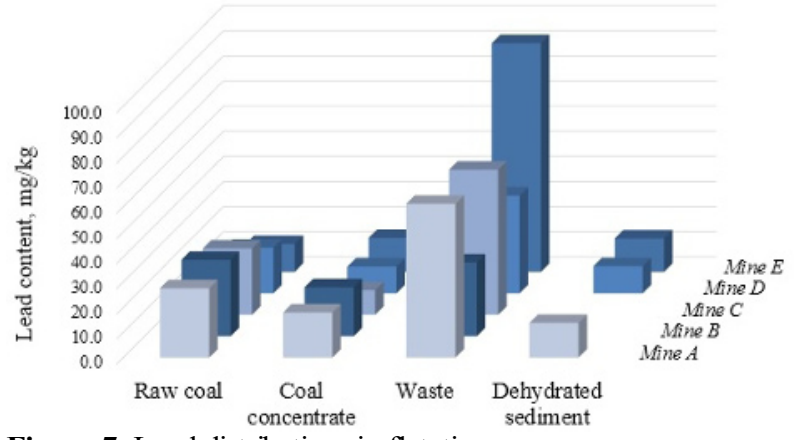

Figure 7. Lead distribution in flotation.

The feed for flotation contains the biggest amount of lead compared to the feeds for other sections of the coal cleaning process $(22.7 \mathrm{mg} / \mathrm{kg})$, which affects its high content in the waste, even up to $91.0 \mathrm{mg} / \mathrm{kg}$. The dehydrated sediments contain a similar amount of lead to the coal concentrates $(12.6 \mathrm{mg} / \mathrm{kg})$.

\subsection{Effect of lead reduction in coal through coal cleaning process}

The effectiveness of the reduction of the lead content in coal was determined by comparing the content of the analysed element in the coal before and after the cleaning process, according to the formula (1) [42]:

$$
\eta_{P b 1}=\frac{c_{\text {raw_coal }}-c_{\text {coal_concentrate }}}{c_{\text {raw_coal }}} \cdot 100
$$

where $\eta_{\mathrm{Pb} 1}$ represents the reduction ratio of the lead content in coal, \%; $\mathrm{c}_{\text {raw_coal }}$ - the $\mathrm{Pb}$ content in the feed, $\mathrm{mg} / \mathrm{kg}$, and $\mathrm{c}_{\text {coal_concentrate }}$ - the $\mathrm{Pb}$ content in the coal concentrate, $\mathrm{mg} / \mathrm{kg}$.

The effectiveness of the reduction of the content of the investigated metal in coal was calculated by means of the ratio which takes into account the calorific value of the feed and the coal concentrate according to the formula (2) [42]:

$$
\eta_{P b 2}=\frac{\frac{c_{\text {raw_coal }}}{Q_{i_{-} \text {raw_coal }}^{a}}-\frac{c_{\text {coal_concentrate }}}{Q_{i_{-} \text {coal_concentrate }}^{a}}}{\frac{c_{\text {raw_coal }}}{Q_{i_{-} \text {raw_coal }}^{a}}} \cdot 100
$$

where $\eta_{\mathrm{Pb} 2}$ represents the $\mathrm{Pb}$ reduction ratio, $\%$; $\mathrm{Q}^{\mathrm{a}_{\mathrm{i}} \text { raw_coal }}$ - the calorific value of the feed, $\mathrm{kJ} / \mathrm{kg}$ (in analytical state); $\mathrm{Q}^{\mathrm{a}} \mathrm{i}_{\text {_coal_concantrate - the calorific value of the coal }}$ concentrate, $\mathrm{kJ} / \mathrm{kg}$ (in analytical state).

The results of these calculations for each of the coal cleaning process sections are shown in Table 4. The highest ratio of lead content reduction in the examined coals was recorded for the gravity methods, for both dense medium washers and jigs. This type of coal cleaning eliminates up to $53 \%$ of the lead content in coal for dense medium washers and $54 \%$ for jig washers. The flotation also enables a high degree of lead removal from coal, except for the case of mine $\mathrm{E}$, for which the result indicates the enrichment of the concentrate with lead. Therefore, excluding the mine $\mathrm{E}$, the average value of the degree of lead content reduction in coal is $44 \%$.

Table 4. Lead content reduction index for examined coal

\begin{tabular}{|c|c|c|c|c|c|c|c|}
\hline \multirow{2}{*}{ Factor } & \multirow{2}{*}{$\begin{array}{l}\text { Type of coal } \\
\text { cleaning }\end{array}$} & \multicolumn{6}{|c|}{ Mine } \\
\hline & & $\mathbf{A}$ & B & $\mathrm{C}$ & D & $\mathbf{E}$ & Average \\
\hline \multirow{3}{*}{$\eta_{\mathrm{Pbl}}[\%]$} & $\begin{array}{l}\text { Dense medium } \\
\text { washery }\end{array}$ & 50 & - & 73 & 66 & 24 & $53 \pm 22$ \\
\hline & Jig washer & 59 & 47 & 58 & 56 & 50 & $54 \pm 5$ \\
\hline & Flotation & 35 & 36 & 63 & 41 & -22 & $31 \pm 32$ \\
\hline \multirow{3}{*}{$\eta_{\mathrm{Pb} 2}[\%]$} & $\begin{array}{l}\text { Dense medium } \\
\text { washery }\end{array}$ & 75 & - & 92 & 90 & 59 & $79 \pm 15$ \\
\hline & Jig washer & 71 & 71 & 70 & 69 & 65 & $69 \pm 3$ \\
\hline & Flotation & 46 & 58 & 71 & 56 & -6 & $45 \pm 30$ \\
\hline
\end{tabular}
cleaning processes.

The effect of reducing the $\mathrm{Pb}$ content in coal is even more clearly visible when its content is compared to the calorific value of raw coal and the coal concentrate obtained in an individual section of the coal cleaning process $\left(\eta_{\mathrm{Pb} 2}\right)$. This illustrates the real environmental effect of the process for coal utilization (combustion, gasification and pyrolysis). The lead content in coal per unit of its calorific value (Fig. 8) was significantly reduced as a result of the coal cleaning process to not more than $0.35 \mathrm{mg} / \mathrm{MJ}$ in the coal concentrates from dense medium washery, $0.40 \mathrm{mg} / \mathrm{MJ}$ in the coal concentrates from jigs and $0.68 \mathrm{mg} / \mathrm{MJ}$ in the coal concentrates from flotation. The reduction ratio of the lead content $\eta_{\mathrm{Pb} 2}$ for cleaning in the dense medium washers is relatively diverse and ranged from $59 \div 92 \%$.

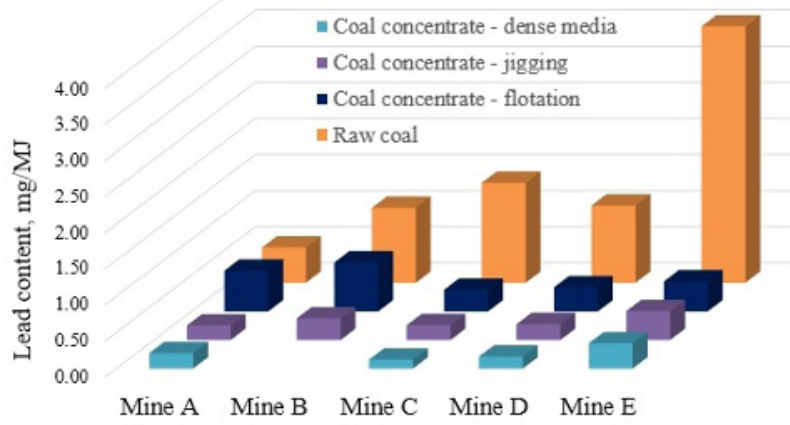

Figure 8. Lead content in raw coals and coal concentrates per unit of calorific value.

The average value of this ratio is $79 \%$, which indicates a very high efficiency of removal of $\mathrm{Pb}$ from coal before its industrial use. For cleaning in jig washers, the $\eta_{\mathrm{Pb} 2}$ ratios for individual mines reach similar values, yielding an average rate of $69 \%$. Flotation is characterized by a ratio of $45 \%$, and, rejecting the result obtained for the mine $\mathrm{E}$, the $\eta_{\mathrm{Pb} 2}$ value would be $58 \%$.

\section{Conclusions}

The study on the possibility of removing lead from coal through its cleaning process in industrial plants allows for the formulation of the following conclusions: 
- Lead in the examined samples of coking coal from the Upper Silesian Coal Basin is associated with coal mineral matter, mainly in the form of galena $(\mathrm{PbS})$ as well as pyrite and marcasite inclusions.

- The industrial processes of coal cleaning successfully remove at least $30 \%$ of lead from coal.

- The greatest efficiency of the removal of lead from coal is achieved through cleaning in dense media and jig washers which reduce $53-54 \%$ of lead.

- The received coal concentrates had an average content of lead equal to $9.3 \mathrm{mg} / \mathrm{kg}$; a lead content per unit of their calorific value was equal to $0.48 \mathrm{mg} / \mathrm{MJ}$ (on average).

\section{Acknowledgements}

This paper was prepared as a part of the statutory activity of the Faculty of Energy and Fuels at the AGH University of Science and Technology, No. 11.11.210.213

\section{References}

1. G.F. Nordberg, B.A. Fowler, M. Nordberg, L. Friberg, Handbook on the toxicology of metals (Elsevier 2007, $3^{\text {rd }}$ edition)

2. A. Kabata-Pendias, H. Pendias, Biogeochemia pierwiastków śladowych (PWN Warszawa 1999)

3. D. C. Adriano, Trace elements in terrestrial environments. Biogeochemistry, bioavailability, and risks of metals (Springer-Verlag, New York 2001)

4. Energy Statistics in 2013 and 2014 - Statistical Information and Elaborations, Central Statistical Office (Warsaw 2015)

5. Environment 2015 - Statistical Information and Elaborations, Central Statistical Office (Warsaw 2015)

6. M.P. Ketris, Ya.E. Yudovich, Int J Coal Geol 78, 135-148 (2009)

7. H. Parzentny, A. Różkowska, Przegląd Geologiczny 2, 52-56 (1990)

8. H. Parzentny, Przegląd Górniczy 6, 33-36 (1991)

9. H. Parzentny, Przegląd Górniczy 2, 25-29 (1992)

10. H. Parzentny, A. Różkowska, L. Róg, Geol Q 43 (3), 365-374 (1999)

11. H. Parzentny, L. Lewińska-Preis, Chem ErdeGeochem 66, 227-247 (2006)

12. H. Parzentny, Energetyka 443, 169-171 (1991)

13. H. Parzentny, Geol Q 38, 1, 43-58 (1994)

14. J. Hower, J.D. Robertson, Int J Coal Geol 53, 219225 (2003)

15. S.F. Diehl, M.B. Goldhaber, J.R. Hatch, Int J Coal Geol 59, 193-208 (2004)

16. F. Goodarzi, Fuel 81, 1199-1213 (2002)

17. R.B. Finkelman, Fuel Process Technol 39, 21-34 (1994)

18. J. Wang, A. Sharma, A. Tomita, Energ Fuel 17, 2937 (2003)

19. H. Parzentny, A. Różkowska, Przegląd Geologiczny 11, 656-659 (1992)

20. H. Parzentny, Przegląd Górniczy 46, 3 (798), 16-19 (1990)

21. M. Marczak, H. Parzentny, Przegląd Geologiczny 12, 680-683 (1985)
22. H. Parzentny, Górnictwo i Geologia 2, 4, 69-81 (2007)

23. J.N. Pacyna, Pr. Nauk. Inst. Inż. Ochr. Środ. Pol. Wrocł. 47, seria Monoografie 17 (1980)

24. H. Parzentny, L. Róg, Górnictwo i Geologia 2, 3, 81 91 (2007)

25. J. Stanisz, A. Pasoń-Konieczyńska, J. Konieczyński, , Arch Environ Prot 26, 7-20 (2000)

26. J. Kuhl, Przegląd Górniczy 2 (1980)

27. H. Parzentny, L. Róg, Przegląd Górniczy 7-8, 52-60 (2001)

28. J.A. Ratafia-Brown, Fuel Process Technol 39, 139157 (1994)

29. R. Yan, D. Gauthier, G. Flamant, Fuel 80, 2217-2226 (2001)

30. S.V. Vassilev, G.M. Eskanazy, C.G. Vassileva, Fuel Process Technol 72, 103-129 (2001)

31. M. Xu, R. Yan, C. Zheng, Y. Oiao, J. Han, C. Sheng, Fuel Process Technol 85, 215-237 (2004)

32. Y. Liu, C. Liu, Y. Shen, F. Tian, H. Liu, F. Shi, Pol J Environ Stud 25, 1, 205-212 (2016)

33. R. Guo, J. Yang, D. Liu, Z. Liu, J Anal Appl Pyrolysis 70, 555-562 (2003)

34. S. Scaccia, R. Mecozzi, Microchem J 100, 48-54 (2012)

35. Krajowa Strategia Ograniczania emisji metali cięzkich, Ministerstwo Środowiska (Warszawa 2002)

36. A. Strugała, J. Gołaś, Mercury as a coal combustion pollutant (Oficyna Drukarska - Jacek Chmielewski, Kraków 2014)

37. K. Jóźwik, M.I. Szynkowska, P. Kula, P. Niedzielski, R. Pietrasik, J. Góralski, Przem Chem 93, 8, 1339 (2014)

38. C. Zhu, H. Tian, K. Cheng, K. Liu, K. Wang, S. Hua, J. Gao, J. Zhou, J Clean Prod, 1-9 (2015)

39. W. Blaschke, Przeróbka węgla kamiennego. Wzbogacanie grawitacyjne, Instytut Gospodarki Surowcami Mineralnymi i Energią PAN (Kraków 2009)

40. E. Zajusz-Zuber, J. Konieczyński, Arch Environ Prot 40, 1, 115 (2014)

41. H. Aleksa, F. Dyduch, K. Wierzchowski, Górnictwo i Geoinżynieria 31, 3, 35 (2007)

42. D. Makowska, K. Bytnar, T. Dziok, T. Rozwadowska, Przem Chem 93, 12, 2048-205 (2014)

43. A. Strugała, D. Makowska, K. Bytnar, T. Rozwadowska, Polityka Energetyczna - Energy Policy Journal 17, 4, 77-88 (2014) 